\title{
STRATEGI KOMUNIKASI BADAN KEPENDUDUKAN DAN KELUARGA BERENCANA NASIONAL (BKKBN)
}

\author{
Herdiana Ayu Susanti \\ Alvin Photography Studio, Jl. Anggajaya III Condong Catur Yogyakarta, No Hp. \\ 08995017704, \\ Email : dianaayuu91@gmail.com
}

\begin{abstract}
This study aims to determine communication strategy of Population and Family Planning Agency (BKKBN) Special Region of Yogyakarta in disseminating Generation Program Planning (GenRe). The study uses descriptive qualitative method. The result shows that communication strategy undertaken by BKKBN Yogyakarta Province in disseminating the program GenRe is through Student Ambassador Selection genre, GenRe Goes To School and GenRe Goes To Campus, Genre Comedy Competition, Poster Competition genre, and Competition NGE - rap genre. BKKBN also uses mass media as a medium of socialization such as Public Service Announcements on television and radio, internet media by creating a website, blog, facebook, and twitter, as well as the use of billboards appeal board. BKKBN also works with schools and colleges to form the Youth Information and Counseling Center / Student (PIK R/M) to get closer to teenagers and college students.
\end{abstract}

Key words: communication strategy, disseminating, BKKBN

\begin{abstract}
Abstrak
Penelitian ini bertujuan mengetahui strategi komunikasi Badan Kependudukan dan Keluarga Berencana Nasional (BKKBN) Provinsi Daerah Istimewa Yogyakarta dalam mensosialisasikan Program Generasi Berencana (GenRe). Penelitian menggunakan metode kualitatif deskriptif. Hasil penelitian menunjukkan bahwa strategi komunikasi yang dilakukan BKKBN Provinsi Daerah Istimewa Yogyakarta dalam mensosialisasikan Program GenRe yaitu melalui Pemilihan Duta Mahasiswa GenRe, GenRe Goes To School dan GenRe Goes To Campus, Lomba Komedi GenRe, Lomba Poster GenRe, dan Lomba Nge-rap GenRe. BKKBN Provinsi DIY juga menggunakan media massa sebagai media sosialisasi seperti Iklan Layanan Masyarakat di televisi dan radio, media internet dengan membuat website, blog, facebook, dan twitter, serta penggunaan papan himbauan baliho. BKKBN Provinsi DIY juga bekerjasama dengan sekolah dan perguruan tinggi dengan membentuk Pusat Informasi dan Konseling Remaja/Mahasiswa (PIK R/M) untuk lebih mendekatkan diri pada remaja dan mahasiswa.
\end{abstract}

Kata kunci: strategi komunikasi, sosialisasi, BKKBN

\section{Pendahuluan}

PendudukIndonesiamemilikijumlah sangat besar mulai dari Sabang sampai Merauke. Jumlah penduduk Indonesia saat ini mencapai 237 juta jiwa dan menduduki urutan keempat terbanyak di dunia. Ada 64 juta anak perempuan dan laki-laki yang berumur 10-24 tahun, atau 27 persen dari jumlah penduduk Indonesia (http://jatim.bkkbn.go.id/ diakses pada tanggal 31 Januari 2013). Laju pertumbuhan penduduk Indonesia mengalami peningkatan setiap tahunnya. Jika tidak dikontrol, Indonesia akan mengalami ledakan penduduk yang cukup besar beberapa tahun mendatang. Ledakan penduduk tersebut tentu saja akan menimbulkan ancaman seperti kemiskinan dan kelaparan.

Pemerintah Indonesia telah membuat suatu kebijakan untuk menekan angka pertumbuhan penduduk yaitu dengan program Keluarga Berencana (KB). Pemerintah Indonesia mencanangkan program KB yaitu pada tahun 1957, pada tahun itu program KB masih secara tradisional yaitu secara pijit, ramuan, dan lain-lain. Penerapan keluarga berencana biasanya dilakukan pada saat pemerintah kurang mampu untuk mengimbangi 
tingkat laju pertumbuhan penduduk, dengan kebutuhan serta fasilitas yang dapat menjamin kesejahteraan penduduknya. Jumlah penduduk yang besar dapat menjadi potensi penggerak menjadi negara kuat jika penduduknya berkualitas. Namun potensi dari jumlah penduduk Indonesia yang sangat besar kurang mampu dioptimalkan oleh pemerintah, hal ini terlihat dari daya saing Indonesia dimana masih tertinggal jauh dibanding Negara lain, bahkan negaranegara Afrika (http://indonesia-negriku. blogspot.com/2010_09_01_archive.html diakses tanggal 2 November 2013).

Memasuki orde baru, program KB mulai menjadi perhatian pemerintah. Saat itu PKBI sebagai organisasi yang mengelola dan concern terhadap program KBmulaidiakuisebagaibadanhukumoleh departemen kehakiman. Pemerintahan orde baru yang menitikberatkan pada pembangunan ekonomi, mulai menyadari bahwa program KB sangat berkaitan erat dengan pembangunan ekonomi. Program yang diluncurkan pada masa orde baru itu terbilang sukses, karena terbukti telah mengantarkan Soeharto ke New York untuk menerima penghargaan bidang kependudukan dari Perserikatan Bangsa-bangsa tahun 1988. Seperti yang diungkapkan oleh Suyono Hadinoto selaku Direktur Analisis Dampak Kependudukan Badan Kependudukan dan Keluarga Berencana Nasional (BKKBN) ada beberapa hal yang menyebabkan program Keluarga Berencana (KB) di era kepemimpinan Presiden Soeharto berhasil:

“....Lonjakan jumlah penduduk yang terus meningkat pascapenerapan otonomi daerah setelah reformasi ini diakibatkan tidak adanya lagi pola kepemimpinan yang bersifat sentralistik. Bahkan pada zaman Orde Baru, program Keluarga Berencana (KB) dijadikan sebagai alat ukur kesuksesan kepala daerah dalam membangun desanya, dengan menekan tingkat rasio kependudukan. Ketika Pak Harto semua berjalan karena sentralisasi, sistem komando ketat. Bahkan KB itu adalah sebagai alat ukur apakah bupati itu sukses atau tidak" (http://health. liputan6.com/read/359124/alasanprogram-kb-zaman-orba-sukses diakses tanggal 2 November 2013).

Kemudian pada tahun 1970 resmilah program KB menjadi program pemerintah dengan ditandai pencanangan hari keluarga nasional pada tanggal 29 Juni 1970. Pada tanggal tersebut pemerintah mulai memperkuat dan memperluas program KB ke seluruh Indonesia. Pada tahun tersebut BKKBN resmi sebagai lembaga yang mengelola Program KB. Program KB mempunyai sebuah moto yaitu "dua anak lebih baik" motto itu dipakai karena penduduk Indonesia yang telah menikah pada masa sebelum dirintis KB memiliki anak dengan jumlah banyak. Hal ini dikarenakan sebuah kepercayaan bahwa banyak anak banyak rezeki sehingga stiap pasangan bisa melahirkan sampai 11 orang. Program KB telah berpengaruh terhadap pertumbuhan penduduk di Indonesia sekarang karena sudah banyak penduduk Indonesia yang mengikuti program KB walaupun belum semua penduduk Indonesia yang mengikuti program tersebut. Namun, penduduk Indonesia yang mengikuti program tersebut telah membantu pemerintah dalam menekan pertumbuhan penduduk di Indonesia.

Memasuki era reformasi, program KB mulai dilupakan oleh masyarakat Indonesia. Masyarakat Indonesia mulai tidakmempedulikan program pemerintah yang dahulu sukses menekan angka laju pertumbuhan penduduk Indonesia. Generasi muda saat ini sudah tidak mengenal program KB. Kemunduran dari Program KB pada masa reformasi salah satunya dikarenakan otonomi 
daerah. Pemerintah pusat sudah tidak bisa memerintahkan ke tingkat bawah. Dibutuhkan leader yang kuat ditingkat provinsi untuk menerapkan program KB tersebut. Saat ini era otonomi daerah atau desentralisasi. Jadi, BKKBN harus secara kuat mengkoordinasikan programprogramnya dengan daerah.

Beberapa tahun belakangan ini, program KB mulai digalakkan lagi dan ditargetkan untuk remaja dikarenakan untuk mempersiapkan remaja-remaja untuk berumah tangga dan mematangkan usia dalam menikah. Program KB sudah ditambah targetnya dahulu yang hanya untuk pasangan suami istri, sekarang program KB di khususkan bagi penduduk Indonesia yang berstatus sebagai remaja. Remaja banyak yang seharusnya belum waktunya untuk menikah tetapi karena terjerumus dalam hubungan yang terlampau jauh sehingga mereka harus menikah pada usia yang tidak seharusnya. Remaja tidak mendapat informasi yang cukup tentang bagaimana seharusnya mereka berhubungan dalam pacaran yang sudah menjadi trend budaya remaja sekarang dan juga sekarang banyak para remaja yang sembarangan melakukan hubungan seksual tanpa didasari pengetahuan yang cukup tentang bahaya melakukan hubungan seksual secara sembarangan atau disebut free sex. Remaja merupakan salah satu kelompok penduduk yang harus dibina secara terus menerus dan dimantapkan, sehingga memiliki sikap dan perilaku yang mendukung pelembagaan sekaligus pembudayaan Norma Keluarga Kecil Bahagia Sejahtera (NKKBS).

Selain program Keluarga Berencana yang berfungsi untuk mempersiapkan remaja-remaja untuk berumah tangga dan mematangkan usia dalam menikah, KB untuk remaja juga dibuat untuk memberikan informasi tentang cara merawat kesehatan reproduksi pada remaja, mengetahui hak-hak reproduksi pada remaja dan juga untuk memberikan informasi tentang reproduksi oleh karena itulah pemerintah menambah target program KB yang dibawahi atau dalam pengawasan BKKBN kepada remaja yaitu tidak lain untuk menjadikan "Anak Indonesia Harapan Masa Depan”.

BKKBN mencanangkan berbagai macam program yang berkaitan dengan kependudukan dan kualitas penduduk termasuk generasi muda. Untuk memperkenalkan KB kepada remaja, maka BKKBN tengah gencargencarnya mengkampayekan salah satu program mereka, yang disebut dengan Generasi Berencana (GenRe). Program KB untuk remaja ini atau program GenRe didukung dengan didirikannya PIK KRR (Pusat Informasi dan Konsultasi Kesehatan Reproduksi Remaja). PIK KRR didirikan untuk membantu remaja dalam memperoleh informasi yang benar tentang reproduksi baik dalam hal cara merawat organ reproduksi dan juga bertujuan untuk menjadikan reproduksi yang sehat dalam segala aspek. Organisasi ini sangat membantu pemerintah untuk mensukseskan program KB untuk remaja sehingga tujuan pemerintah untuk menjadikan "Anak Indonesia Harapan Masa Depan" dapat tercapai.

Program BKKN yaitu Generasi Berencana (GenRe) sasarannya adalah kalangan remaja setingkat SMA dan mahasiswa. Melalui program ini yang diselingi dengan informasi soal keluarga berencana, kalangan muda memiliki planning (rencana) untuk bagaimana mempersiapkan keluarganya dengan perencanaan yang matang. Program ini perlu disosialisasikan oleh BKKBN untuk mengajak masyarakat khususnya para remaja, agar dapat merencanakan masa depan yang lebih baik. GenRe ini sebetulnya sudah ada sejak lama, hanya saja sekarang kembali digiatkan dengan 
nama yang lebih friendly di telinga anak muda, dan diperbaharui lagi programprogramnya. Program ini dibuat untuk remaja agar bisa merencanakan kehidupan setelah masa remaja, antara lain, di usia berapa akan menikah, punya keturunan, atau hal-hal yang berkaitan dengan kesehatan reproduksi. Untuk saat ini, program GenRe berfokus pada Triad Kesehatan Remaja yaitu Say No to Drugs, Say No to Free Sex and Say Goodbye HIV/ AIDS.

Deputi Bidang Keluarga Sejahtera dan Pemberdayaan Keluarga (KSPK) Badan Kependudukan dan Keluarga Berencana Nasional (BKKBN) Dr. Sudibyo Alimoeso mengungkapkan:

“.......Melalui program GenRe ini diharapkan dapat meminimalisir atau mengurangi para remaja melakukan seks di luar nikah yang dapat berakibat kehamilan yang tidak diinginkan, tidak pakai narkoba, dan terhindar dari HIV/AIDS. Kehamilan di luar nikah seringkali merugikan remaja putri yang masih sekolah karena tidak boleh lagi melanjutkan sekolahnya. Disinilah kita perlu meningkatkan ketahanan keluarga". (http://www.bkkbn. go.id/ diakses pada tanggal 29 Januari 2013)

Program ini memperkenalkan KB kepada remaja juga menjauhkan remaja dari perbuatan beresiko seperti, seks bebas, penyalahgunaan narkoba, hingga terinfeksi HIV/AIDS. Dengan demikian, perencanaan yang telah disusun tidak terkendala oleh ketiganya. Berbagai kegiatan yang sudah dilakukan sebagai upaya untuk mendekatkan diri dan mensosialisasikan pada masyarakat khususnya kalangan muda mengenai program Generasi Berencana (GenRe) salah satunya BKKBN mengadakan Pemilihan Duta Mahasiswa GenRe 2012. Sedikitnya 64 mahasiswa dari 32 provinsi, kecuali Bangka Belitung, mengikuti pemilihan Duta Mahasiswa GenRe 2012 ini. Kegiatan yang berlangsung selama 4 hari tersebut, bertujuan untuk memilih figur motivator dari kalangan mahasiswa dan akan lebih mempermudah dalam promosi dan sosialisasi program GenRe di lingkungan mahasiswa dan masyarakat umum (http://fisip.unrika. ac.id/ diakses pada tanggal 29 Januari 2013).

BKKBN juga meluncurkan GenRe Action 2012 yaitu Lomba Poster Nasional yang merupakan ruang publik bagi pencurahan daya kreatifitas, ekspresi dan sosialisasi generasi muda dengan tema Generasi Muda Berencana Menuju Indonesia Sejahtera. Kegiatan ini diikuti oleh 33 provinsi di Indonesia dan masing-masing provinsi mengirimkan perwakilan dalam tiga kategori yaitu kategori umum, mahasiswa, dan SMA. BKKBN juga menggelar GenRe Goes To School yang berisi acara talk show, pentas seni dan beragam perlombaan di sekolah-sekolah. Kepanitiaan kegiatan ini melibatkan pengelola sekolah, pendidik sebaya, dan konselor sebaya PIK (Pusat Informasi Konseling) remaja yang ada di sekolah yang bersangkutan.

Bagi kalangan mahasiswa ada program GenRe Goes To Campus. Kemudian juga diadakan Lomba Komedi GenRe 2012. Acara ini dikemas agar menarik perhatian masyarakat khususnya para remaja. Media seni termasuk komedi mudah dilakukan dan banyak digemari oleh masyarakat. Ini sangat baik untuk mensosialisasikan konsep-konsep generasi berencana. Informasi melalui komedi akan mudah dipahami oleh semua segmen. Tetapi sasaran utama adalah para remaja.

Kegiatan-kegiatan yang diadakan BKKBN tersebut merupakan sebuah media komunikasi dalam mensosialisasikan program GenRe. Untuk itu perlu adanya strategi komunikasi yang dilakukan BKKBN dalam mensosialisasikan program GenRe. Program GenRe ini perlu dikomunikasikan dan 
disosialisasikan dengan baik, agar generasi muda Indonesia khususnya benar-benar mendapatkan pengetahuan dan memiliki sikap sesuai dengan yang dikehendaki oleh BKKBN. Maka dari itu, dibutuhkan startegi komunikasi yang baik agar pesan yang ingin disampaikan kepada generasi muda dapat diterima dan direalisasikan dengan baik.

Strategi komunikasi yang dilakukan harus sesuai dengan karakteristik si penerima pesan. Jika program ini memang ditujukan untuk generasi muda, maka kegiatan-kegiatan yang dibuat harus menarik minat dan sesuai trend anak muda jaman sekarang. Karena komunikasi itu tidak hanya sekedar informatif tetapi juga harus persuasif, yaitu agar orang lain bersedia menerima suatu paham atau keyakinan melakukan suatu perbuatan atau kegiatan, dan lainlain. Menurut Carl I. Hovland dalam Effendy (2007:10), bahwa komunikasi adalah proses mengubah perilaku orang lain (communication is the process to modify the behavior of other individuals). Akan tetapi, seseorang akan dapat mengubah sikap, pendapat, atau perilaku orang lain apabila komunikasinya itu memang komunikatif dan efektif.

Strategi komunikasi merupakan perencanaan dan manajemen komunikasi. Dalam rangka menyusun strategi komunikasi diperlukan suatu pemikiran dengan memperhatikan faktor-faktor pendukung dan faktor-faktor penghambat. Strategi komunikasi dalam mensosialisasikan sebuah program harus mencakup tiga unsur penting agar komunikasi berjalan efektif, yaitu mulai dari daya tarik dan kredibilitas komunikator, karakteristik pesan, serta media yang dipilih dan digunakan. Apabila komunikasi berjalan efektif maka, lebih mudah untuk mencapai tujuan yang diinginkan. Untuk itu, peneliti tertarik untuk meneliti bagaimana strategi-strategi yang dilakukan Badan Kependudukan dan Keluarga Berencana Nasional (BKKBN) Provinsi Yogyakarta dalam mensosialisasikan program Generasi Berencana (GenRe) agar generasi muda Indonesia dapat menjadi generasi yang berkualitas.

Strategi komunikasi erat hubungannya antara tujuan yang hendak dicapai dengan konsekuensi-konsekuensi (masalah) yang harus diperhatikan, kemudian merencanakan bagaimana konsekuensikonsekuensi sesuai dengan hasil yang diharapkanatau tujuan yang akan dicapai. Tujuan yang ingin dicapai oleh Badan Kependudukan dan Keluarga Berencana Nasional (BKKBN) menurut Dr Sudibyo Alimoeso Deputi bidang KSPK Badan Kependudukan dan Keluarga Berencana Nasional (BKKBN). "Melalui program Genre ini diharapkan para remaja, mampu menjadikan dirinya dan anak cucunya kelak sebagai manusia Indonesia yang berkualitas serta meminimalisir atau mengurangi para remaja melakukan seks di luar nikah yang dapat berakibat kehamilan yang tidak diinginkan, tidak pakai narkoba, dan terhindar dari HIV/ AIDS". (http://www.bkkbn.go.id/ diakses pada 31 Januari 2013)

Tujuan tersebut akan sangat sulit diwujudkan dan disosialisasikan tanpa adanya strategi komunikasi yang baik dan tepat sasaran. Untuk mencapai tujuan komunikasi yang diinginkan perlu melakukan strategi perencanaan komunikasi. Penelitian ini menggunakan teori perencanaan pesan dimana pesan yang ingin disampaikan oleh BKKB Provinsi DIY melalui tahapan perencanaan. Perencanaan merupakan cara bagaimana agar sebuah tujuan atau target yang diinginkan tercapai. Dalam komunikasi, pesan menjadi salah satu unsur penentu efektivitas tidaknya suatu tindakan komunikasi. Menurut Robbins dan Jones (1986:51) dalam Ritonga 
(2005:4), yang vital bagi komunikasi ialah menyusun dan mengatur pesan-pesan sedemikian rupa, hingga memproleh respons yang diingini daripada hanya suatu respons begitu saja. Rakhmat (1991:295) dalam Ritonga (2005:4) dengan tegas mengatakan bahwa peyajian pesan yang tersusun akan lebih efektif daripada penyajian pesan yang tidak tersusun. Pesan akan dapat menghasilkan respons tertentu kalau dirancang dengan baik.

Adapun rumusan masalah yang diteliti adalah bagaimana strategi komunikasi Badan Kependudukan dan Keluarga Berencana Nasional (BKKBN) Provinsi Daerah Istimewa Yogyakarta dalam mensosialisasikan program Generasi Berencana (GenRe)?

\section{Metode Penelitian}

Metode penelitian yang digunakan adalah metode deskriptif kualitatif yaitu pengamatan, wawancara, atau penelaahan dokumen. Penelitian kualitatif yaitu penelitian yang menggunakan manusia sebagai instrumen penelitian utama dan mengandalkan terutama bentukbentuk naratif untuk mengkode data dan menulis teks untuk disajikan kepada khalayak (Mulyana, 2002:158). Penelitian yang menghasilkan data deskriptif berupa kata-kata tertulis atau lisan dari orang-orang dan perilaku yang dapat diamati. Pendekatan ini diarahkan pada latar individu tersebut secara holistik (utuh). Penelitian yang bermaksud untuk memahami fenomena tentang apa yang dialami oleh subjek penelitian misalnya perilaku, persepsi, motivasi, tindakan secara holistik dan dengan cara deskripsi dalam bentuk kata-kata dan bahasa pada suatu konteks khusus yang alamiah dan dengan memanfaatkan berbagai metode alamiah (Moleong, 2008:6).

Penelitian ini melibatkan objek penelitian yaitu strategi komunikasi yang digunakan oleh Badan Kependudukan dan Keluarga Berencana Naasional
Provinsi Daerah Istimewa Yogyakarta dalam mensosialisasikan program Generasi Berencana (GenRe) bagi generasi muda Indonesia agar paham tentang program KB, dapat terhindar dari hal-hal negatif yang mengancam generasi muda saat ini, seperti seks bebas, narkoba, dan HIV/AIDS dan dapat merencakan masa depannya dengan baik.

Sumber data dalam penelitian ini adalah pertama, informan atau narasumber yang diwawancarai, yang terdiri dari Badan Kependudukan dan Keluarga Berencana Nasional (BKKBN) Provinsi Daerah Istimewa Yogyakarta, pihak sekolah atau perguruan tinggi yang pernah bekerjasama dalam kegiatan program GenRe Goes To School dan GenRe Goes To Campus serta Pemilihan Duta Mahasiswa GenRe, dan peneliti juga mewawancarai beberapa pelajar dan mahasiswa. Data yang diperoleh melalui sumber-sumber lain, yaitu; Dokumentasi, yaitu pengumpulan data sekunder mengenai obyek penelitian yang didapat dari sumber tertulis, seperti majalah, buku, majalah ilmiah, sumber arsip, dokumen pribadi, foto, dokumen resmi dan sebagainya yang mendukung analisa penelitian. Teknik analisa data yang digunakan dalam penelitian ini adalah teknik analisis interaktif (Interactive Model of Analysis). Menurut Miles dan Huberman, terdapat tiga komponen utama dalam penelitian kualitatif yaitu (1) reduksi data, (2) sajian data, dan (3) penarikan simpulan serta verifikasinya (Sutopo, 2002:91).

\section{Hasil Penelitian dan Pembahasan}

Program GenRe yang dicanangkan pada tahun 2009 oleh BKKBN sebagai wujud kepedulian terhadap masa depan generasi muda bangsa Indonesia yang saat ini perkembangannya semakin mengkhawatirkan terjerumus ke hal-hal yang negatif dan mulai tidak mengenal program KB (Keluarga Berencana). 
Program GenRe merupakan program yang dibuat oleh BKKBN pusat dan diselenggarakan oleh setiap BKKBN provinsi yang ada di Indonesia untuk dapat disosialisasikan kepada seluruh masyarakat Indonesia.

Program GenRe merupakan program yang ditujukan kepada warga negara Indonesia terutama remaja (usia 10-24 tahun) dan belum menikah, keluarga dan masyarakat peduli remaja ini, diharapkan mampu mempromosikan penundaan usia kawin, penyediaan informasi kesehatan reproduksi seluas-luasnya sehingga mereka mampu melangsungkan jenjang pendidikan secara terencana, berkarir dalam pekerjaan secara terencana, serta menikah dengan penuh perencanaan sesuai siklus kesehatan reproduksi, dan diharapkan mampu mengatasi persoalan kuantitas dan kualitas penduduk (khususnya remaja) sekaligus, tidak terjebak pada penyalahgunaan Napza, HIV dan AIDS maupun kehamilan yang tidak diinginkan serta mempromosikan perencanaan kehidupan berkeluarga atau Keluarga Berencana (KB) dengan sebaik-baiknya (kapan menikah, kapan mempunyai anak, berapa jumlah anaknya $\mathrm{dsb}$ ) agar masa depan lebih baik.

“Program Generasi Berencana adalah program di mana diharapkan semua orang terutama remaja mempunyai perencanaan yang baik sebelum berkeluarga. Jadi, diharapkan saat remaja mempunyai perencanaan yang baik, apa saja yang harus dipersiapkan dalam memasuki masa perkawinannya, seperti merencanakan akan punya anak berapa, bagaimana nanti masa depannya, dan diharapkan dapat membangun keluarga yang sejahtera. Program GenRe ini lebih ditujukan kepada remaja agar remaja benar-benar siap menjadi tegar remaja yang artinya terbebas dari Triad KRR yaitu seks bebas, napza, dan HIV/ AIDS. (Hasil wawancara dengan Pak Ewang
Sewoko, staf bidang Keluarga Sejahtera dan Pemberdayaan Keluarga BKKBN Provinsi DIY pada tanggal 5 Juni 2013)."

Tujuan dari program GenRe ini agar remaja benar-benar siap menjadi remaja yang tegar, terhindar dari Triad KRR, yaitu seks bebas, napza, dan HIV/ AIDS sehingga masa depannya terjamin dan dapat terencana dengan baik. Triad KRR adalah tiga risiko yang dihadapi oleh remaja/mahasiswa, yaitu risikorisiko yang berkaitan dengan seksualitas, napza, HIV dan AIDS. Jika generasi muda Indonesia terjerumus dalam pergaulan seks bebas dan napza, maka akan terjangkit HIV/AIDS. Bukan hanya itu saja, pergaulan dan seks bebas di kalangan remaja juga mengakibatkan semakin tingginya angka pernikahan dini. Dalam hal ini, sangat erat kaitannya dengan tidak tercapainya tujuan pengenalan Keluarga Berencana kepada remaja. Seperti yang diketahui tujuan Keluarga Berencana yaitu untuk menekan angka laju pertumbuhan penduduk agar tidak terjadi ledakan penduduk. Jika, angka kelahiran terus meningkat maka program Keluarga Berencana di Indonesia terancam gagal. Angka pernikahan dini juga sangat mempengaruhi keberhasilan pengenalan program KB kepada remaja. Seperti di Daerah Istimewa Yogyakarta pergaulan dan seks bebas kian menjamur di tengah masyarakat. Setiap tahun angka pernikahan dini di DIY semakin meningkat.

\section{Strategi Komunikasi}

Sebuah strategi komunikasi sangat penting direncanakan demi tercapainya tujuan dari program yang akan disosialisasikan. Strategi komunikasi dilakukan untuk mencapai tujuan yaitu memperkenalkan program KB melalui terobosan program GenRe kepada generasi muda agar peduli dengan masa depannya. Hal ini berkaitan dengan paduan perencanaan komunikasi dan 
manajemen komunikasi yang dilakukan oleh BKKBN Provinsi Daerah Istimewa Yogyakarta.

Selain bekerjasama dengan perguruan tinggi yang ada di Yogyakarta dengan membentuk Pusat Informasi dan Konseling Mahasiswa (PIK-M) untuk mensosialisasikan program GenRe melalui komunikasi intepersonal, BKKBN Provinsi Daerah Istimewa Yogyakarta juga menyelenggarakan acara-acara atau kegiatan yang berkaitan dengan sosialisasi program GenRe. Kegiatan tersebut diantaranya seperti Pemilihan Duta Mahasiswa GenRe tingkat provinsi, GenRe Goes To School dan GenRe Goes To Campus, Komedi GenRe, dan Lomba Poster GenRe.

Pemilihan Duta Mahasiswa GenRe ini bertujuan untuk memilih seorang figur atau contoh motivator dari kalangan mahasiswa dan sebagai icon panutan bagi remaja yang memiliki pengetahuan yang luas, memiliki perencanaan untuk masa depannya, mengetahui dan paham tentang kesehatan reproduksi dan materi mengenai program GenRe itu sendiri. BKKBN juga meluncurkan kegiatan yaitu GenRe Goes To School dan GenRe Goes To Campus dalam rangka sosialisasi program GenRe kepada generasi muda terutama pelajar dan mahasiswa. Dalam acara GenRe Goes To School dan GenRe Goes To Campus berisi kegiatan seperti penyuluhan, informasi tentang kesehatan reproduksi, seksualitas, narkoba, HIV/ AIDS, dan permainan-permainan edukasi. Kegiatan-kegiatan tersebut dilaksanakan agar menarik minat remaja akan adanya program terobosan dari BKKBN untuk memperkenalkan program KB yaitu program GenRe.

Banyak hal yang harus diperhatikan dalam menyusun strategi komunikasi diantaranya seperti yang dirumuskan oleh Harold Laswell yaitu Who Says What In Which Channel To Whom With What
Effect. Telain komunikator, pesan, siapa khalayak, dan efeknya, media komunikasi apa yang dipakai juga penting dalam menyampaikan informasi atau sosialisasi sebuah program agar pesan tersampaikan dan diterima dengan baik oleh khalayak.

Media komunikasi banyak jumlahnya, mulai dari yang tradisional sampai yang modern dewasa ini banyak dipergunakan seperti contohnya: pagelaran kesenian, surat, papan pengumuman, telepon, telegram, pamflet, poster, spanduk, surat kabar, majalah, film, radio, televisi, dan sebagainya. Pada umumnya media komunikasi diklasifikasikan sebagai media cetak, visual, audio, dan audio-visual. Tetapi dapat juga diklasifikasikan sebagai media lini atas dan media lini bawah.

Setiap strategi komunikasi pasti memiliki tujuan yang ingin dicapai, begitu pula dengan strategi komunikasi yang digunakan dalam sosialisasi program GenRe oleh BKKBN juga memiliki tujuan yang ingin dicapai. Program GenRe ini sasaran komunikasinya remaja atau generasi muda (umur 10-24 tahun). Untuk mencapai sasaran komunikasi dapat dipilih salah satu atau gabungan dari beberapa media, tergantung dari tujuan yang akan dicapai, pesan yang akan disampaikan, dan teknik yang digunakan. Masing-masing media mempunyai kelebihan dan kekurangan.

BKKBN Provinsi DIY melakukan sosialisasi dan pendidikan, pentransferan budaya berupa pengenalan program Keluarga Berencana (KB), pendewasaan usia perkawinan untuk menekan laju angka pertumbuhan penduduk dan meningkatkan kesejahteraan masyarakat. BKKBN Provinsi Daerah Istimewa Yogyakarta bekerjasama dengan televisi dan radio lokal yang ada di Yogyakarta. Televisi lokal diantaranya TVRI dan Jogja TV, sedangkan untuk radio hampir semua radio lokal Jogja yang diajak berekrjasama. Hal ini dimaksudkan 
agar informasi yang disampaikan dapat menjangkau lebih luas dan lebih banyak khalayak. BKKBN juga tidak lupa untuk menyasar anak muda lewat media sosial internet karena responnya lebih positif dan feedback dapat diterima lebih cepat. Pesan-pesan yang disampaikan melalui jejaring sosial facebook cenderung lebih santai dan menggunakan bahasa yang tidak formal sesuai dengan karakter anak muda. Cara-cara penyampaian tersebut cenderung lebih mengena untuk anak muda karena anak muda jaman sekarang tidak mau terlalu merasa digurui dan senang diposisikan sebagai teman sebaya.

"Seharusnya Pusat Informasi dan Konseling Reproduksi Remaja (PIK KRR) itu wajib adanya di setiap sekolah menengah, ngabayangin kejahatan seksual di kalangan remaja ini banyak sekali....kasian kan remaja kita, para remaja ini harus menjaga kesehatan reproduksinya untuk menghindari kejahatan seksual, dan para remaja ini dihimbau untuk berperilaku positif. trus agamanya diperkuat kaliiii ya". (http:// www.facebook.com/BKKBNOnline/ status update GenRe BKKBN tanggal 6 Maret 2013)

Strategi komunikasi menggunakan media luar ruang ini juga diterapkan oleh BKBBN Provinsi Daerah Istimewa Yogyakarta dalam mensosialisasikan program Generasi Berencana (GenRe). Papan himbauan baliho ditempatkan di tempat yang strategis seperti perempatan jalan yang mudah dilihat oleh komunikan. Baliho tersebut adalah salah satu contoh baliho program GenRe yang ditempatkan di perempatan jalan lingkar (ring road) selatan Terminal Giwangan. Isi pesannya berbunyi "Rencanakan Masa Depan Hindari Pernikahan Dini" dan ada tulisan Generasi Berencana yang menunjukkan bahwa papan baliho tersebut ditujukan untuk generasi muda sesuai sasaran program Generasi
Berencana (GenRe) yaitu himbauan agar generasi muda merencanakan masa depan dan menghindari pernikahan dini.

Dalam strategi komunikasi yang ditentukan oleh BKKBN Provinsi DIY, perencanaan pesan atau merancang pesan untuk sosialisasi program GenRe sangat dibutuhkan demi tercapainya tujuan dari sosialisasi itu sendiri. Perencaan pesan yang dilakukan mulai dari mempersiapkan materi-materi tentang apa itu kesehatan reproduksi remaja, pendewasaan usia perkawinan, bahaya seks bebas, napza, dan HIV/AIDS, apa itu Keluarga Berencana (KB) dan apa manfaat program $K B$ ke depannya. Kemudian materi-materi atau pesan tersebut dikemas baik dengan bahasa dan cara yang tidak terlalu vulgar dan menggurui remaja serta tentunya dapat dimengerti dan mudah dipahami oleh remaja agar remaja tidak salah pengertian. Perencanaan pesan komunikasi berkaitan dengan tujuan apa yang ingin dicapai melalui strategi komunikasi. Perencanaan pesan yang dibuat oleh BKKBN Provinsi Daerah Istimewa Yogyakarta bersifat infromatif dan persuasif. Hal ini terlihat pada pemilihan kata atau kalinat-kalimat yang digunakan dalam berbagai media komunikasi, baik secara langsung maupun melalui media massa. Sosialisasi biasanya melibatkan berbagai sumber komunikasi yang berbeda seperti media massa, advertensi atau promosi, penyuluhan, jejaring atau media sosial internet, atau kontak-kontak sosial yang informal. Media massa dan promosi berfungsi untuk menciptakan kesadaran dan pengetahuan para remaja/ mahasiswa dan masyarakat pada umumnya tentang adanya program Generasi Berencana (GenRe) yang sangat bermanfaat bagi remaja, penyuluhanpenyuluhan berguna untuk mempersuasi remaja/mahasiswa agar paham tentang program $\mathrm{KB}$, menerapkan dan menjadi 
generasi yang memiliki perencanaan masa depan dan menghindari Triad KRR (seks bebas, napza, dan HIV/ AIDS), pengaruh antarpribadi seperti konseling berfungsi bagi keputusan untuk menerima dari program GenRe, dan pengalaman dalam menerapkan hidup positif dapat menjadi sumber konfirmasi untuk terus menerapkannya menjadi generasi yang berencana atau sebaliknya.

Peranan komunikasi dalam proses sosial yaitu perubahan sosial dapat disebabkan karena komunikasi. Program GenRe merupakan alat untuk terjadinya perubahan sosial pada kehidupan remaja. Melalui komunikasi, perubahan sosial akan terjadi karena proses komunikasi menghasilkan perubahan-perubahan pengertian, dalam proses komunikasi terjadi sosialisasi nilai, komunikasi telah terbukti sebagai cara yang efektif dalam hal penyebaran pesan, memberikan pemahaman, komunikasi merupakan cara penularan perilaku, dan komunikasi berhubungan dengan pemanfaatan media massa. Strategi komunikasi yang telah dilakukan oleh BKKBN Provinsi DIY harus memperhatikan tujuan sentral kegiatan komunikasi yaitu ada tiga tujuan utama (1) to secure understanding yakni memastikan bahwa komunikan mengerti pesan yang diterima, (2) to establish acceptance, jika komunikan sudah mengerti dan menerima maka perlu terus dibina, dan (3) to motive action, kegiatan komunikasi tersebut dimotivasikan. Seperti halnya program Generasi Berencana (GenRe) yang digalakkan BKKBN Provinsi DIY, apabila sudah dapat memastikan para remaja/mahasiswa sudah mengerti pesan yang diterima tentang GenRe maka BKKBN Provinsi DIY harus terus membina remaja untuk menerapkan GenRe di kehidupannya, dan tentunya terus memotivasi remaja.

Tujuan dari kegiatan komunikasi yaitu terciptanya efek bagi khalayak.
Efek yang ditimbulkan dari kegiatan sosialisasi program Generasi Berencana ini masih pada tahap kognitif saja belum sampai pada tahap behavioral. Ada beberapa faktor yang ikut mempengaruhi proses penerimaan pesan. Jadi, pesan itu tidak langsung diterima individu, tetapi dipikirkan, dan dipertimbangkan, apakah mau menerima pesan-pesan tersebut atau tidak. Pengaruh lingkungan, orangtua dan teman pergaulan dari remaja sangat berpengaruh dalam keberhasilan mengubah pola pikir seorang remaja untuk terhindar dari Triad KRR, yaitu seks bebas, napza, dan HIV/AIDS, serta menghindari pernikahan dini untuk meraih cita-cita dan masa depan yang lebih baik. Pembinaan terhadap keluarga yang memiliki remaja juga harus terus dijalankan agar dapat menciptakan generasi muda yang berkualitas.

Melihat dari hasil penelitian, efek tercapainya tujuan dari sosialisasi program GenRe ini untuk remaja belum jelas terlihat. Efeknya hanya sebatas pengetahuan saja atau informasi, untuk persuasi belum dapat tercapai karena masih tingginya angka pernikahan dini dan perilaku negative di kalangan remaja. Program ini memerlukan biaya atau anggaran dana yang tidak sedikit. Program GenRe belum banyak diketahui oleh pelajar dan mahasiswa. Hanya sekolah/universitas tertentu yang megetahui program GenRe, bahkan perguruan tinggi yang memiliki Pusat Informasi dan Konseling Mahasiswa (PIK-M) sebagian besar mahasiswanya tidak mengetahui adanya PIK-M tersebut. PIK-M unggulan yang pada tahap Tegar Center Of Exellence (COE) juga belum dimanfaatkan para mahasiswa untuk datang dan berkonsultasi atau sharing dan mencari informasi mengenai kesehatan reproduksi secara benar. Dilihat dari indikator keberhasilannya, PIK-M sebagai pusat informasi dan konseling 
belum dapat terpenuhi mulai dari promosi melalui TV lokal, radio, koran lokal, dan lain-lain, pengelolaan PIK-M juga tidak maksimal, akses dan kualitas pelayanan PIK-M, dan meningkatnya jumlah remaja yang mendapat pelayanan di PIK-M. BKKBN Provinsi Daerah Istimewa Yogyakarta juga belum pernah melakukan pemantauan dan pembinaan kepada PIK-M yang ada di universitasuniversitas setelah launching PIK-M tersebut. Semestinya BKKBN ProvinsiDIY tetap terus memberikan pendampingan kepada PIK-M dan PIK-R yang ada di sekolah dan universitas-universitas agar dapat berjalan sebagaimana mestinya sesuai dengan tujuan yang ingin dicapai.

Program Generasi Berencana di Provinsi Daerah Istimewa Yogyakarta juga belum dapat menyasar sampai ke pedesaan-pedesaan, hanya di kabupaten/kota saja. Hal tersebut kembali lagi karena keterbatasan dana dari pemerintah untuk program GenRe ini. Anggaran dana untuk tiap provinsi berasal dari APBN saja belum maksimal, harus ada anggaran dari APBD. BKKBN Provinsi Daerah Istimewa Yogyakarta harus melakukan evaluasi program dan kegiatan-kegiatan yang telah dilakukan, apakah berjalan optimal dan efektif atau hanya membuang-buang anggaran dana dari pemerintah. Harus ada peremajaan kegiatan yang membuat generasi muda tertarik dan mau terlibat dalam program GenRe tersebut.

\section{Simpulan}

Strategi komunikasi BKKBN dilakukan melalui berbagai kegiatan yang ditujukan langsung khususnya bagi kawula muda atau generasi muda terutama pelajar dan mahasiswa. Kegiatan-kegiatan tersebut diantaranya seperti Pemilihan Duta Mahasiswa GenRe, GenRe Goes To School, GenRe Goes To Campus, Lomba Poster, dan Komedi GenRe. Kegiatan tersebut dapat menjadi sarana atau media komunikasi yang menarik untuk menyampaikan informasi mengenai program GenRe mulai dari apa itu program Generasi Berencana (GenRe), apa manfaatnya untuk generasi muda, dan sebagainya yang berkaitan dengan program GenRe. Selain itu, sosialisasi juga dilakukan dengan pendekatan secara interpersonal atau komunikasi interpersonal oleh BKKBN Provinsi Daerah Istimewa Yogyakarta dengan membentuk Pusat Informasi dan Konseling Remaja dan Mahasiswa (PIK-R/M) bekerjasama dengan sekolahsekolah dan universitas di Yogyakarta.

Hasil dari strategi komunikasi yang dilakukan oleh Badan Kependudukan dan Keluarga Berencana Nasional Provinsi DIY dalam mensosialisasikan Program Generasi Berencana belum efektif dan belum dapat dikatakan berhasil. Hal tersebut dapat dilihat dari hasil survei angka pernikahan dini, seks bebas, penggunaan napza, dan HIV/AIDS masih cukup tinggi dan cenderung meningkat di wilayah Yogyakarta didominasi oleh remaja.

Pembentukan Pusat Informasi dan Konseling Remaja/Mahasisa (PIK$\mathrm{R} / \mathrm{M}$ ) juga belum berjalan sebagaimana mestinya karena remaja/mahasiswa masih sungkan untuk datang konsultasi dengan orang yang tidak dikenalnya di PIK-R/M tersebut. Mereka lebih memilih bercerita dengan teman dekatnya.

Implikasi dari hasil penelitian ini bahwa bkkbn harus melakukan sosialisasi tentang keluarga berencara kepada generasi muda menggunakan berbagai media.

\section{Daftar Pustaka}

Effendy, Onong Uchjana. (2007). Ilmu Komunikasi (Teori dan Praktek). Bandung : PT. Remaja Rosdakarya.

Moleong, Lexy. (2008). Metodologi Penelitian Kualitatif. Bandung : PT. Remaja Rosdakarya. 
Sutopo. (2002). Metodologi Penelitian Kualitatif. Surakarta: Sebelas Maret University Press.

http://jatim.bkkbn.go.id/ diakses pada tanggal 31 Januari 2013.

http: / / indonesianegriku.blogspot. com/2010_09_01_archive.html diakses tanggal 2 November 2013.

http: / / health.liputan6.com / $\mathrm{read} / 359124 /$ alasan-program-kbzaman-orba-sukses diakses tanggal 2 November 2013. http://www.bkkbn.go.id/ diakses pada tanggal 29 Januari 2013.

http://fisip.unrika.ac.id/ diakses pada tanggal 29 Januari 2013.

http://www.bkkbn.go.id/ diakses pada tanggal 31 Januari 2013.

http: / / w w w.face book.com / BKKBNOnline/ diakses tanggal 3 April 2013. 